\title{
LOWER COURT INFLUENCE ON U.S. SuPREME COURT OPINION CONTENT*
}

\author{
Bryan Calvin \\ btcalvin@unt.edu \\ Department of Political Science \\ University of North Texas \\ Paul M. Collins, Jr. \\ pmcollins@unt.edu \\ Department of Political Science \\ University of North Texas \\ Pamela C. Corley \\ pamela.corley@,vanderbilt.edu \\ Department of Political Science \\ Vanderbilt University
}

\begin{abstract}
Despite the importance of Supreme Court opinions for the American polity, scholars have dedicated little systematic research to investigating the factors that contribute to the content of the Court's opinions. In this paper, we examine the ability of lower federal courts to shape the content of Supreme Court opinions. We argue that lower court opinions will influence the content of the Court's opinions based on a number of factors, including the prestige of the lower court opinion author, the published or unpublished nature of the lower court opinion, the ideological compatibility of the lower court opinion vis-à-vis the Supreme Court's decision, the type of lower court opinion, and the lower court from which the opinion emanated. Utilizing plagiarism detection software to compare lower federal court opinions with the majority opinions of the Supreme Court during the 2002-2004 terms, we uncover support for our hypotheses, indicating that the Supreme Court systematically incorporates language from the lower federal courts into its majority opinions.
\end{abstract}

Paper Prepared for Delivery at the $67^{\mathrm{TH}}$ AnNual MeEting of the Midwest Political SCIENCE Association, ChiCAgo, Illinois, April 2-5, 2009

\footnotetext{
* Collins thanks the University of North Texas for a research grant that partially funded the collection of the data used in this project.
} 
When the United States Supreme Court renders a decision, the Court's opinion becomes binding precedent, constraining the decision making of future Supreme Courts, lower court judges, and executive branch agencies charged with adjudicating disputes related to the case. In addition, attorneys marshal the language of judicial opinions in an attempt to secure their clients favorable outcomes and these opinions provide the justification for the Court's decisions, allowing the justices to engage in a dialogue with the citizenry (e.g., Bennett 2001). Given the significance of Supreme Court opinions for lower courts, bureaucratic agencies, future Supreme Courts, litigators, and the public, in order to comprehend the law, and the political system more generally, one must have an understanding of how Supreme Court opinions are crafted. However, scholars have dedicated little systematic research to investigating the factors that contribute to the content of Court's opinions. In this paper, we examine the extent to which lower federal court opinions influence the content of the U.S. Supreme Court's majority opinions. Specifically, we compare federal district court and courts of appeals opinions with the majority opinions of the Supreme Court using plagiarism detection software, which provides substantial insight into the ability of lower courts to shape the content of Supreme Court opinions.

The importance of understanding the content of Supreme Court opinions cannot be overstated. Legal scholars, practitioners, lower court judges, bureaucrats, and the public closely analyze judicial opinions, dissecting their content in an endeavor to understand the doctrinal development of the law. Through the close analysis of the content of Supreme Court opinions, the meaning and consistency of various rulings within particular areas of law becomes apparent. Such is the case because it is through its opinions that the Supreme Court promulgates rules and tests that act as precedent, constraining the decisions of lower courts (Corley 2008: 469). Despite this, political scientists in the quantitative tradition have virtually ignored the content of the Court's opinions, 
focusing instead on case outcomes and the justices' voting behavior in those cases. While we do not deny the significance of studying case outcomes, it is clear that a case is more than its outcome. As Shapiro (1968: 39) notes, "the opinions themselves, not who won or lost, are the crucial form of political behavior by the appellate courts, since it is the opinions which provide the constraining directions to the public and private decision makers who determine the 99 percent of conduct that never reaches the courts." Simply put, understanding the content of judicial opinions is imperative for a more complete command of the development of the law.

In order to comprehend the content of the Court's opinions, one must recognize that the Court does not operate in a vacuum. Rather, the legal rules articulated in the Court's opinions are very much shaped by the actors involved in the litigation environment (Wahlbeck 1997). When a case reaches the Supreme Court, the justices rely primarily on four sources of information to render their decisions (e.g., Stern et al. 2002). First, the plenary conflict in any given case involves the parties to litigation, which attempt to persuade the Court to render a favorable decision through their legal briefs. Second, interest groups provide the Court with their own subjective interpretations of the correct application of the law by filing amicus curiae ("friend of the court") briefs. Third, the justices obtain information regarding the litigants' desired applications of law at oral arguments, in which each litigant is typically granted thirty minutes to persuade the justices to endorse its position. Finally, the justices obtain information to assist them in adjudicating the controversy based on the opinions of the lower courts that initially disposed of the case. ${ }^{1}$

\footnotetext{
${ }^{1}$ In addition to these information sources, on rare occasions the justices hear from intervenors to the case, who are allowed to file their own briefs and participate at oral arguments under statutory law or when they can demonstrate a direct stake in the outcome of the case (e.g., Stern et al. 2002). Moreover, the justices may conduct their own legal research or direct their clerks to do so (e.g., Ward and Weiden 2006).
} 
While political scientists have generally failed to systematically address how these informational sources influence the Court's opinions, a small body of research reveals that the Court's opinions are shaped by the party's briefs on the merits (e.g., Corley 2008), amicus curiae briefs (e.g., Samuels 2004; Spriggs and Wahlbeck 1997), and oral arguments (e.g., Johnson 2004). Specifically, Corley (2008) compares the litigants' briefs with the majority opinions of the Court utilizing plagiarism detection software and finds that the percentage of the Court's majority opinions coming from each party's brief is driven by the quality of the brief, the ideological compatibility of the brief's argument with the Court, and the political salience of the case. With regard to amicus briefs, Samuels (2004) and Spriggs and Wahlbeck (1997) uncover evidence that the Supreme Court's majority opinions adopt language and legal rules forwarded by interest groups. Relating to oral arguments, Johnson's (2004) analysis indicates that the Court focuses a major portion of its opinions on issues that are discussed during oral arguments. Despite the significant progress that has been made toward scientifically understanding the content of Supreme Court opinions, scholars have not yet systematically addressed the extent to which lower courts influence the content of the Court's opinions.

The fact that this lacuna in our understanding of Supreme Court opinion content exists is troubling. To remedy this state of affairs, we embark on the task of examining the influence of lower court opinions on the Supreme Court's majority opinions. Exploring this relationship is significant for a number of reasons. First, this research provides a more complete picture of the factors that shape the content of Supreme Court opinions than currently exists. Indeed, Justice Thomas is especially clear in articulating the significance of lower court opinions at the Supreme Court. Thomas explains the process by which the justices deliberate cases on the merits as follows: "We work through the case, as I read the briefs, I read what they've written, I read all of the cases 
underlying, the court of appeals, the district court. There might be something from the magistrate judge or the bankruptcy judge. You read the record" (quoted in Greenburg 2007). As Thomas makes evident, the justices do not start from scratch in their deliberation of cases. Rather, they digest the lower court opinions, litigant briefs, and amicus curiae briefs, all of which have the potential to shape the doctrinal content of the justices' opinions. Second, this research is important in that it sheds fresh light on how the Supreme Court interacts with lower courts. While there is a voluminous literature on this topic, it overwhelmingly focuses on lower court interpretation of, and compliance with, Supreme Court precedent (e.g., Canon and Johnson 1999; Klein 2002; Sanders 1995), ignoring how lower courts shape Supreme Court precedents. As such, the current paper holds the promise of illustrating the ability of lower courts to shape the doctrinal course of federal law as it is articulated in Supreme Court opinions. Finally, this research is significant in that it views the judicial system as a web of interactions among different levels of federal judiciary. Rather than studying a single court without regard to its relationship to other courts, we paint a much more realistic picture of the federal judiciary by examining how the Supreme Court incorporates the language of lower court opinions into its own opinions that set precedent for the entire American judiciary.

\section{THE MEANing OF Lower COURT INFLUENCE}

There are myriad methods by which lower courts can influence the Supreme Court. A lower court opinion that demonstrates a strong grasp on the corpus of federal law might motivate the justices to deny a certiorari petition, shaping the Court's agenda setting decisions. A well-crafted lower court opinion might induce the justices to affirm the lower court ruling, influencing the ultimate outcome of the case. Conversely, a rogue lower court that steps too far out of line with existing law may motivate the justices to reverse that court's decision, again influencing a case's 
disposition. Here, we focus on perhaps the most significant means of influence: the ability of lower court opinions to shape the content of Supreme Court majority opinions.

In order to avoid any unnecessary confusion, it is imperative that we are clear with respect to what we mean by influence in the current context. By "influence," we are referring to the ability of lower court opinions to shape the content of Supreme Court opinions and thus the behavior of Supreme Court justices. Specifically, we contend that when the Supreme Court's majority opinion utilizes the same language as the lower court opinion, the lower court has affected the nature and substance of the opinion, indicating that the lower court has influenced the doctrinal development of federal law. To be clear, this does not necessarily indicate that the lower court has influenced the decision of the Court (e.g., reverse or affirm), but it does provide evidence that the lower court has shaped the development of the law (e.g., Corley 2008). ${ }^{2}$

The Supreme Court can incorporate the language of lower court opinions into its own opinions in a variety of different ways. The Supreme Court might favorably adopt a rule applied in the lower court to dispose of the case at the high court. Alternatively, the Supreme Court might specifically criticize a rule adopted by the lower court and explain why it is poorly conceived or inapplicable to the case at hand. In either instance, the lower court has shaped the development of the Supreme Court's opinion. In addition, the Supreme Court might borrow language from the lower court opinion that specifically relates to the lower court's discussion of precedent or statutory law. That is, if the lower court opinion quotes from another source, such as statutory law, and the Supreme Court uses that same quotation in its opinion, this provides for the opportunity that litigants, lower courts, and future Supreme Courts may use that phrase at a later date, again evincing

\footnotetext{
${ }^{2}$ That the Supreme Court's majority opinion incorporates language from the lower court opinion does not necessarily indicate causation because we are unable to account for how the majority opinion might have been crafted if the content of the lower court opinion was different (e.g., Corley 2008).
} 
the ability of lower courts to shape federal law through their influence on Supreme Court opinions. Moreover, the Supreme Court might adopt the lower court's recitation of the facts of a dispute, which can affect, not only the content of the Supreme Court's opinion, but also the Court's outcomes (e.g., Segal 1986). When the Supreme Court engages in the process of applying the facts of the case to the rule of law, the Court determines the operative facts of the litigation. In so doing, the Court may "rulify" a standard, in which the explicit application of a standard manifests itself as a rule for use in future litigation (Rosen 2005). If the Supreme Court's majority opinion recites the facts from the lower court opinion, this provides evidence that the lower court has successfully persuaded the Court to adopt its view of the facts (Corley 2008: 470). ${ }^{3}$

As these examples make clear, there are a wide array of means by which the Supreme Court might incorporate the language of lower court opinions into the Court's own opinions. In some instances, the result is a favorable treatment of the lower court opinion. In others, the result is a negative treatment of the lower court opinion. Regardless of whether the Supreme Court's integration of the language of lower court opinions into its opinions is positive or negative, when the Court utilizes the lower court opinions as the basis for its opinions, this provides evidence of lower court influence on the Supreme Court. Because our purpose here is to provide a generalizable and systematic examination into the ability of lower court opinions to influence Supreme Court majority opinions, we do not disentangle these various forms of influence. This allows us to move beyond the more common case studies that track the doctrinal development of particular legal rules or tests

\footnotetext{
${ }^{3}$ We recognize that, when the Supreme Court integrates the facts of the case or a discussion of precedent from the lower court opinion into is own opinion, this is not necessarily indicative of lower court influence. It is plausible that the Supreme Court does so because it agrees with the characterization of the facts or is persuaded by the arguments contained in the precedent cited by the lower court opinion. Nonetheless, if the Supreme Court incorporates language from lower court opinions into its own majority opinions in a systematic manner, this provides fairly compelling evidence of lower court influence.
} 
and, instead, provide quantitative insight into lower court influence on Supreme Court opinion content.

\section{LOWER COURT INFLUENCE ON SUPREME COURT OPINIONS}

Below, we present our theoretical expectations involving the factors that affect the extent to which lower courts influence the content of Supreme Court opinions. We hypothesize that the Supreme Court will be more likely to incorporate the language of lower court opinions into its majority opinions depending on the prestige of the lower court opinion author, the published or unpublished nature of the lower court opinion, the ideological compatibility of the lower court opinion with the Supreme Court, the type of lower court opinion, and the court from which the lower court opinion originated.

There is substantial evidence in a variety of literatures that source credibility and prestige is a major determinant as to how individuals evaluate the opinions of others (e.g., Galanter 1974; Harmon and Coney 1982; Hass 1981; Hovland and Weiss 1951). This body of research reveals that highly prestigious individuals are better situated to convince others to more carefully consider the quality and credibility of their opinions than their less prestigious counterparts. Such is the case because prestigious and credible sources are perceived by others as being capable of more complex and reasoned deliberation, thus earning the close attention of individuals evaluating their opinions. The deference granted to prestigious information sources stems from the view that these communicators have advanced knowledge and are therefore trustworthy information sources (e.g., Perloff 2003). Simply put, even when holding the content of the message equal, communicators are more effective if they are perceived to be prestigious.

We believe the legal system is no different. To be sure, lower court judges are not created equal. Some judges enjoy favorable reputations for the quality of their judicial opinions, while others 
are looked upon negatively for sloppy or underdeveloped opinions. As Klein and Morrisroe (1999:

373) highlight, the opinions of judges with prestigious reputations "display particular insight, logic, craftsmanship, or some other similar quality, and so are more persuasive than typical opinions.” Indeed, the import of judicial prestige was corroborated by a courts of appeals judge who was queried as to the significance of judicial reputation:

...It matters very much. I have ratings for judges just like you rate baseball or football players. One of the first things I look at is who wrote the opinion. ... When I see an opinion written by [Judge A, Judge $B$, or Judge $C$, all from the judge's own circuit] I give it a good deal of thought before I disagree. The same with judges from other circuits: Campbell, Breyer; I could go down the list. It's a very big factor. Say there was a panel of $[\mathrm{A}, \mathrm{B}$, and $\mathrm{C}]$ not directly binding on me. It would be very difficult for me - knowing they're consistently fair, learned, researched - I'd be very loath to walk too far away. With other judges, I look and sort of sniff: "This guy's sort of a clown.” I don't like to cite them, even if they come out the way I want to go (quoted in Klein 2002: 95)

While this statement was made by a court of appeals judge discussing the reputations of other circuit court judges, we have no reason to believe Supreme Court justices view judicial reputation any differently. As such, we expect the justices will pay particular attention to the prestige of the lower court opinion author and will be more likely to incorporate the language of lower court opinions authored by distinguished jurists into their own opinions.

H1: Lower court opinions authored by prestigious judges are more likely to influence the content of the Supreme Court's opinion.

Judges serving on the lower federal courts enjoy control over whether their opinions are published, at both the federal district court and courts of appeals levels (e.g., Swenson 2004; Wasby 2004). The formal guidelines for the publication of opinions, outlined in the 1973 Advisory Council on Appellate Justice Report, indicate that opinions should be published largely as a function of the breadth to which they affect federal law. That is, since only published opinions have precedential 
value, the guidelines advise judges to publish opinions that create, alter, or criticize legal rules, involve significant issues of public interest, or resolve conflict between two or more courts. ${ }^{4}$ While the extent to which these rather broad and subjective guidelines are followed varies, evidence nonetheless suggests that published opinions tend to have broad import beyond the parties directly involved in the dispute (e.g., Merritt and Brudney 2001; Swenson 2004; Wasby 2004; cf. Songer 1990).

We hypothesize that lower federal court opinions that are published will be more likely to influence the content of Supreme Court opinions than unpublished opinions. First, because these opinions have significance beyond the parties to litigation and the specific facts of the case, we expect that Supreme Court justices will be especially interested in the development of the legal rules in the lower court opinions for use as a guide in the formation of the Court's own legal rules. Related, because published opinions tend to be longer and more complex than unpublished opinions, published opinions evince better developed legal doctrines than unpublished opinions (Wasby 2004: 81). In this sense, judges expend more time and energy deliberating over the content of published opinions, knowing that they will likely be cited in future litigation. In contrast, because unpublished opinions are targeted at the litigants, judges focus more on the rule of law enunciated in unpublished opinions as it relates to the litigants, as opposed to the broad corpus of federal law. Third, because lower court judges, as opposed to their clerks, are inclined to author published opinions (Wasby 2004: 95), these opinions reflect the experience of seasoned jurists, as compared to relatively green clerks who are often charged with drafting unpublished opinions. As such, published

\footnotetext{
${ }^{4}$ Though these guidelines are intended to provide clarity over the decision to publish an opinion, the fact remains that both circuit and district courts have their own guidelines for the publication of opinions, although circuit and district-specific guides largely mimic those of the Advisory Council (e.g., Songer 1990; Wasby 2004).
} 
opinions demonstrate more thorough, and often less sloppy, deliberation over the jurisprudential content of the opinion.

H2: Lower court opinions that are published are more likely to influence the content of the Supreme Court's opinion than unpublished opinions.

For more than a half century, students of the Supreme Court have recognized the paramount role of ideology in shaping the justices' choices (e.g., Pritchett 1948; Segal and Spaeth 2002). The effect of ideology is so ubiquitous that it influences the justices' decision making in a host of contexts, including the Court's agenda setting (e.g., Perry 1991), the justices' receptivity to oral arguments (e.g., Johnson, Wahlbeck, and Spriggs 2006), the treatment of litigant briefs (e.g., Corley 2008), decisions on the merits (e.g., Segal and Spaeth 2002), and the crafting of opinions (e.g., Maltzman, Spriggs, and Wahlbeck 2000). Moreover, past research demonstrates that a lower court's ideological compatibility with the Supreme Court plays a strong role in determining whether the Supreme Court will reverse or affirm the lower court (e.g., Scott 2006).

Following from this research, we expect that the Supreme Court will be more likely to incorporate the language of lower court opinions that are ideologically congruent with the Supreme Court's decision. For example, when the Supreme Court's decision is liberal in its direction, and the court of appeals opinion is also liberal, we anticipate that the Supreme Court will be more likely to borrow from the court of appeals decision, as compared to an instance in which the court of appeals opinion is conservative in its ideological direction. First, in so doing, the Supreme Court is potentially rewarding the lower court for acting as a faithful agent. That is, by integrating the language of lower court opinions into its own opinions, the Supreme Court enhances the extent to which the lower court is able to contribute to the development of federal law via Supreme Court precedents. Second, by incorporating the language of an ideologically congruent lower court into its opinion, this provides a shortcut for the justices, reducing the resource costs of engaging in research 
beyond that which is presented by the litigants, amici, and lower courts. In other words, because the lower court opinion is consistent with the ideological direction of the Supreme Court's decision, it is an efficient use of the justices' finite time and resources to borrow language from the lower court opinion. ${ }^{5}$

\section{H3: Lower court opinions that are ideologically consistent with the Supreme Court's decision are more likely to} influence the content of the Supreme Court's opinion.

At the lower federal court level, judges have a variety of options with respect to the types of opinions they author or join. Opinions representing the court's decision and reasoning are majority opinions for courts of appeals and three-judge district court panels, while the opinions of single judges perform an analogous function at the district court level. In addition to majority opinions, judges serving on collegial courts (i.e., courts of appeals or three-judge district court panels), occasionally author separate opinions that concur, dissent, or concur in part and dissent in part from those courts' majority opinions. To be sure, these separate opinions perform a very different function than majority opinions. Majority opinions serve as authorities for later cases and, thus, act as precedent. Through majority opinions (or single-judge district court opinions), the court articulates the rule of law established in the case, which theoretically acts as a binding force for future litigation. ${ }^{6}$ Unlike majority opinions, separate opinions have no precedential force. Rather, separate opinions represent only the views of those judges who concur or dissent from the

\footnotetext{
${ }^{5}$ Our empirical model does not distinguish as to whether the Supreme Court's opinion positively or negatively treats the lower court opinion. Regardless of a positive or negative treatment, we believe the justices will be more likely to borrow language from lower court opinions that are ideologically compatible with the Supreme Court's decision since the justices are likely to be drawn to arguments, consciously or not, that mesh with their attitudes (e.g., Kunda 1990).

${ }^{6}$ The breadth of the precedential force of majority opinions depends, of course, on the level of the court system. Courts of appeals precedents are binding on the circuit as a whole and are frequently cited outside the circuit (e.g., Klein 2002). District court precedents are much more fragile in that they are not binding on any level of the American legal system, although they may be treated as precedents by other district court judges (Morriss, Heise, and Sisk 2005: 70).
} 
majority's decision. While separate opinions do play an important role in the American legal system (e.g., Hettinger, Lindquist, and Martinek 2006), in the eyes of courts and litigants, they are less significant than majority opinions since only majority opinions have precedential value.

Given the differences in these types of opinions, we hypothesize that the Supreme Court will be more likely to incorporate the language of majority opinions (or single-judge district court opinions) than separate opinions. That is, like other actors in the judicial system, we expect the Supreme Court will more closely scrutinize majority opinions than separate opinions as a function of the precedential value of majority opinions. Inasmuch as the Court might give majority opinions special attention, we expect the justices will be more likely to borrow from majority opinions since they establish a rule of law that is potentially binding on the jurisdiction of the lower court from which the opinion emanated.

H4: Lower court majority opinions are more likely to influence the content of the Supreme Court's opinion than separate opinions.

The federal courts operate within a hierarchy of justice. The district courts sit at the bottom of this hierarchy and are charged with the initial resolution of disputes between litigants. In the process of resolving these controversies, district court judges are enabled to make policy, particularly in cases of first impression in which there exists no existing precedent at either the circuit court or Supreme Court levels (Rowland and Carp 1996: 3). The courts of appeals constitute the intermediate appellate courts in the federal judiciary. These courts perform the first—and typically final—review of appeals from the federal district courts. In so doing, the courts of appeals make policy by setting precedents that are binding on federal district courts and future courts of appeals panels within the circuit (e.g., Hettinger, Lindquist, and Martinek 2006; Klein 2002).

We believe that a court's place in the federal judiciary hierarchy will influence the Supreme Court's reliance on the language used in that court's opinion. More specifically, we hypothesize that 
the Supreme Court will borrow more language from courts of appeals opinions than district court opinions. First, this stems from the reality that courts of appeals decisions act as binding precedents for the entirety of their circuit. While district court decisions can be used as precedent (e.g., Rowland and Carp 1994: 3) their precedential significance positively pales in comparison to that of the courts of appeals since district court precedents do not formally bind the decisions of federal or state judges (Morriss, Heise, and Sisk 2005: 70). Second, the roles of these courts differ. The district courts operate at the front door of the federal judiciary and their chief responsibility is disposing of controversies relating primarily to the litigants to the suit, which typically involves fact finding. Conversely, the courts of appeals are appellate bodies, correcting errors in the lower court's application of the law, while engaging in broad policy making (e.g., Early 1977). This fact is not lost on Justice Scalia, who explains the differences between trial and appellate courts as follows: "They [trial courts] focus on achieving the proper result in one particular case, not on crafting a rule of law that will do justice in the generality of cases" (Scalia and Garner 2008: 7). In this sense, the courts of appeals and the Supreme Court share much in common in that they are both intimately concerned with the consistency of federal law and their opinions are binding on wider constituencies than district court opinions.

H5: Courts of appeals opinions are more likely to influence the content of the Supreme Court's opinions than district court opinions.

\section{DATA AND METHODS}

To provide an empirical test of our hypotheses, we collected data on U.S. Supreme Court majority opinions and the opinions of the U.S. District Courts and the U.S. Courts of Appeals that previously heard the cases ultimately decided by the Supreme Court during its 2002-2004 terms. ${ }^{7}$ We

\footnotetext{
${ }^{7}$ We recognize that the Supreme Court can incorporate the language of the opinions of specialized federal courts (e.g., federal magistrate judges and other Article I courts) into its own opinions.
} 
initially located the Supreme Court's cases in the Spaeth (2007) database. We then identified the relevant lower court opinions using Westlaw's direct history function, which tracks cases disposed of by the high Court through the legal system, linking each Supreme Court case to the lower court opinions that previously decided each case. The unit of analysis in our data is the Supreme Court opinion-lower court opinion dyad. There are 128 Supreme Court orally argued, signed majority opinions in our data. Each Supreme Court majority opinion is tied to an average of 2.7 lower court opinions. $^{8}$

Having located the Supreme Court's majority opinions and the lower court opinions from which the Supreme Court's decisions originated, we converted the Court's majority opinions, and all of the lower court opinions, into a text format. We then utilized the plagiarism detection software, WCopyfind 2.6 (Bloomfield 2009), to compare each lower court opinion to the Supreme Court's majority opinion (see also Corley 2008; Grimmer 2009). This program allows us to analyze two (or more) text documents to determine the extent to which they share common words in phrases. Following Corley (2008: 471), we set the shortest phrases to match at six words. Thus, the program ignores matches of five words or less. We set the program to ignore letter case, numbers, and outer punctuation. The program was also set to skip non-words (i.e., "words" that contain characters other than letters, with the exception of internal hyphens and apostrophes). The significance of this is that the words in phrases reported by the program do not contain case citations. The program was

However, because we lack measures of judicial prestige for the judges serving on these courts, we exclude them from consideration. While we acknowledge that the opinions of state court judges can also shape the content of the Supreme Court's opinions, because there are difficulties comparing state and federal judges, particularly relating to judicial prestige and the publication of opinions, we focus our attention on the federal courts.

${ }^{8}$ We excluded a small number of procedural opinions from the lower courts, such as the denial of a petition for an en banc hearing (provided there was no dissent from the denial), since these opinions are generally extremely short and do not address the substantive issues implicated in the litigation. 
set such that the shortest string it would consider was one hundred characters. We programmed WCopyfind to allow up to two imperfections, authorizing the software to bridge its way across up to two non-matching words as it connects pieces of perfectly matched phrasing. This enables the program to identify matches despite minor editing to the prose. Finally, we set the minimum percentage of matches that a phrase can contain at eighty. This provides another means to allow the program to identify matches notwithstanding minor editing.

After comparing the Supreme Court's majority opinions to each relevant lower court opinion, WCopyfind generates a report that indicates the percentage of the Supreme Court opinion that borrows directly from the lower court opinion. This percentage constitutes our dependent variable. For example, in Brown v. Legal Foundation of W ashington (2003), a case involving the constitutionality of the mandatory use of interest on lawyers' trust account (IOLTA) programs, Justice Stevens' majority opinion borrowed the following language directly from the Ninth Circuit Court of Appeals' majority opinion:

IOLTA programs spread rapidly because they were an exceedingly intelligent idea. Money that lawyers deposited in bank trust accounts always produced earnings, but before IOLTA, the clients who owned the money did not receive any of the earnings that their money produced. IOLTA extracted the earnings from the banks and gave it to charities, largely to fund legal services for the poor. That is a very worthy purpose (538 U.S. 216, at 232).

To provide some perspective as to the makeup of our dependent variable, Figure 1 is a box plot of the percentage of the Supreme Court's majority opinions that directly incorporates language from lower court opinions, broken down by the Supreme Court justice who authored the majority opinion. This lowest line in the box plot represents the minimum percentage, while the center line in the shaded area represents the median percentage of the majority opinion that "plagiarizes" from the lower court opinions. The upper and lower quartiles of the dependent variable are indicated by the 
lines outside of the shaded area, while outliers are represented by the circles. Over all justices, the mean of our dependent variable is 4.32 , with a standard deviation of $4.38 .^{9}$

\section{[ Figure 1 About Here ]}

As this figure makes clear, there is a good amount of variation with regard to the extent to which each justice incorporates language from lower court opinions into the Supreme Court's majority opinions. Majority opinions authored by Thomas have the highest average percentage (6.22), followed by majority opinions authored by Rehnquist (5.86) and Stevens (5.64). Breyer's opinions have the lowest mean percentage drawn from lower court opinions (2.57), followed by Souter (3.01) and Kennedy (3.20). Rehnquist evinces the highest amount of variability in his reliance on lower court opinions, as indicated by the size of the interquartile range: the extent to which Rehnquist "plagiarized" from lower court opinions ranges from 0 to $23 \%$. This is followed by O’Connor and Thomas, while Kennedy, Ginsburg, and Breyer have the lowest interquartile dispersion.

In order to test factors that shape the Supreme Court's reliance on the language from lower court opinions, we operationalize our independent variables as follows. To capture the prestige of the lower court judges who authored the opinions under comparison, we use the rating each judge received from the American Bar Association (ABA) at the time he or she was nominated to the federal bench (e.g., Hettinger, Lindquist, and Martinek 2006; Klein and Morrisroe 1999). The ABA rates judges according to their qualifications for office and general reputations in the legal community. Over the course of its ratings, the ABA employed four ratings: "not qualified," "qualified," "well qualified," and "exceptionally well qualified." In 1991, the ABA ceased using the

\footnotetext{
${ }^{9}$ This percentage is quite a bit smaller than the percentage of Supreme Court majority opinions drawn from litigant briefs: Corley (2008) finds that, for the 2002 to 2004 terms, the mean percentage of majority opinions "plagiarized" from litigant briefs is $10.7 \%$ for petitioner briefs and $9.4 \%$ from respondent briefs.
} 
"exceptionally well qualified" category. Given that our data contain judges appointed both before and after 1991, our measure of Judicial Prestige is coded such that $1=$ "not qualified," 2 = "qualified," and 3 = "well qualified" or "exceptionally well qualified." We expect this variable will be positively signed.

To measure whether the lower court opinion was published or not, we reviewed each lower court opinion and created a Published Opinion variable, scored 1 for published lower court opinions and 0 for lower court opinions that were not published. The information regarding the publication of lower court opinions is spelled out in Westlaw above the case citation. For courts of appeals decisions, the language corresponding to non-published opinions typically appears as follows: "This case was not selected for publication in the Federal Reporter." For district court opinions, nonpublished opinions are commonly identified with the following language: "Not Reported in F.Supp.2d." We expect this variable will be positively signed.

To capture the ideological compatibility of the lower court opinion with the Supreme Court's majority opinion, we coded each lower court opinion as liberal or conservative, following the coding rules in Spaeth (2007). We then matched the ideological direction of the lower court opinion to that of the Supreme Court's majority opinion. If the lower court opinion was conservative [liberal] and the Supreme Court's majority opinion was also conservative [liberal], our Ideological Congruence variable is scored 1. If the lower court opinion was conservative [liberal] and the Supreme Court's majority opinion was liberal [conservative] this variable is scored 0 (e.g., Collins 2004; Corley 2008). We expect this variable will be positively signed.

To test hypotheses four and five, we employ two variables. Court of Appeals Majority Opinion is scored 1 for court of appeals majority opinions (three-judge panel or en banc) and court of appeals per curiam opinions, and 0 otherwise. District Court Opinion is scored 1 for single-judge district court 
opinions, three-judge district court majority opinions, or three-judge district court per curiam opinions, and 0 otherwise. The reference category is separate opinions (concurring, dissenting, or concurring in part and dissenting in part) corresponding to three-judge courts of appeals panels, three-judge district court panels, or en banc courts of appeals panels. Consistent with hypothesis four, we expect these variables will be positively signed. Following from hypothesis five, we expect the coefficient corresponding to the Court of Appeals Majority Opinion variable will be larger than the coefficient of the District Court Opinion variable. ${ }^{10}$

The final variables in our model enable us to account for other factors that might shape the extent to which Supreme Court majority opinions incorporate language from lower court opinions. First, we employ an Opinion Length variable to capture the reality that the lower court opinions under analysis vary with respect to their length. This variable represents the number of words in each lower court opinion, divided by 1,000 to make the size of the coefficient more manageable. Because longer opinions provide the Supreme Court with more opportunity to borrow from the lower court opinion, we expect this variable will be positively signed. Second, we control for the political salience of the case in order to account for the fact that, in salient cases, the justices might expend more time and energy shaping the content of the majority opinion than in relatively trivial disputes (Corley 2008; Maltzman, Spriggs, and Wahlbeck 2000). The Political Salience variable is scored 1 if the case was covered on the front page of the New York Times on the day after the decision and 0 otherwise (Epstein and Segal 2000). We expect this variable will be negatively signed. Finally, we include

\footnotetext{
${ }^{10}$ There are an assortment of methods to test hypotheses four and five. To ensure the robustness of our results, we experimented with a variety of alternatives, including using dummy variables for each type of opinion in the data. Since the use of various alternative model specifications does not alter the substance of our results, and because the operationalization discussed above provides for a direct test of our hypotheses, for the sake of parsimony we utilize the two dichotomous variables corresponding to courts of appeals majority opinions and district court opinions.
} 
dummy variables for each Supreme Court majority opinion writer, save Chief Justice Rehnquist (who acts as the reference category). As Figure 1 illustrates, there is a good amount of variation with respect to the frequency with which the justices incorporate the language of lower court opinions into their own majority opinions. The inclusion of these dummy variables allows the model to capture this fact (although we do not report the results of the justice-specific dummy variables in the statistical model that follows). ${ }^{11}$ The summary statistics of our variables are reported in Table 1.

\section{[ Table 1 About Here ] \\ RESULTS}

Given the makeup of our dependent variable, we utilize ordinary least squares regression to test the factors that shape the Supreme Court's incorporation of lower court opinions into its own majority opinions. Because each Supreme Court majority opinion appears in the data more than once, in that each majority opinion is tied to an average of 2.7 lower court opinions, we use robust standard errors, clustered on docket number. This allows the model to account for the nonindependence of observations. The empirical results of our model are reported in Table 1 . The model's R-squared value is a respectable 0.292 and the statistically significant F-test indicates that the variables included in this analysis systematically contribute to the extent to which the Supreme Court "plagiarizes" from lower court opinions.

\section{[ Table 2 About Here ]}

Most importantly, the model provides support for all five of our hypotheses. First, we find that the Supreme Court is more likely to incorporate lower court opinions into its majority opinions when the lower court opinion was written by a prestigious judge. In substantive terms, the Supreme

\footnotetext{
${ }^{11}$ We also ran the model including issue-specific dummy variables to control for the issue areas implicated in the cases under analysis. As those variables failed to achieve statistical significance, we exclude them from the model.
} 
Court "plagiarizes" 1.5\% more of a lower court opinion if it was authored by a judge rated "well qualified" or "exceptionally well qualified" by the American Bar Association, as compared to a judge with an "unqualified" rating. This is indicative of the fact that, like courts of appeals judges (e.g., Klein 2002), the justices on the Supreme Court pay close attention to the prestige of the lower court opinion author.

We also find that the Supreme Court is more likely to incorporate lower court opinions that are published. All else equal, the Court incorporates 1.6\% more of published lower court opinions into its majority opinions, as compared to unpublished opinions. This corroborates extant research suggesting that lower court judges devote more time and attention to the doctrinal development of published opinions (e.g., Wasby 2004) and apparently the justices take notice, relying more on published lower federal court opinions in their majority opinions.

Our results indicate that the Supreme Court is more likely to "plagiarize" from lower court opinions that are ideologically congruent with the Court's decision. For example, if the Supreme Court rendered a liberal decision, and the lower court opinion was liberal in its direction, the justices integrate $0.64 \%$ more of the lower court opinion, in contrast to a conservative lower court opinion. This evinces the important role of ideology in the opinion writing process at the Court (e.g., Maltzman, Spriggs, and Wahlbeck 2000). Moreover, it is consonant with Corley's (2008) research indicating that the justices are especially reliant on litigant briefs that are ideologically compatible with the ideological direction of the Court's decision.

Consistent with our fourth and fifth hypotheses, the results illustrate that the Court relies more on majority opinions than separate opinions and is more likely to "plagiarize" from courts of appeals opinions than district court opinions. First, compared to separate opinions, the justices integrate $3.7 \%$ more of courts of appeals majority opinions and $1.5 \%$ more of district court opinions 
into the Supreme Court's majority opinions. Since court of appeals majority opinions (or single judge district court opinions) have precedential value, it is apparent that the justices recognize this fact and pay close import to the doctrinal content of these opinions. Second, Table 1 indicates that the Supreme Court is more reliant on courts of appeals opinions than district court opinions. This is evidenced by the fact that the coefficient for the Courts of Appeals Majority Opinion variable is larger than that of the District Court Opinion variable. More substantively, the Court "plagiarizes" 2.2\% more of court of appeals majority opinions than district court opinions (the reference category are separate opinions for these variables). This indicates that the justices are especially dependent on court of appeals majority decisions as a function of the fact that court of appeals majority opinions have more significant precedential value than district court opinions.

Turning now to the control variables, we find that, as the length of a lower court opinion increases, so too does the Supreme Court's incorporation of language from that opinion. For each additional 10,000 words in a lower court opinion, the Supreme Court incorporates $0.86 \%$ more of the opinion into its majority opinions. We also find that the justices integrate fewer phrases from lower court opinions in salient cases: the Court "plagiarizes" 1.08\% less from lower court opinions in salient cases, as compared to more routine disputes. This is consistent with research indicating that the justices are especially interested in the doctrinal development of the majority opinion in salient cases and expend more time and effort crafting these landmark decisions (Maltzman, Spriggs, and Wahlbeck 2000).

Although the differences in percentages for each variable may seem small, a hypothetical may be more appropriate to understand the effect of these variables. First, we compute the baseline predicted probability of the percentage of the Court's opinion coming from the lower court's opinion when Rehnquist is the opinion writer, which is calculated by holding all continuous variables 
at their mean values while holding all discrete variables at their modal values. The baseline probability is 4.08 percent. When the lower court opinion is a majority court of appeals, published decision, written by a prestigious judge, in a case that is not salient and the word count is 20.422 (one standard deviation above the mean), the predicted percentage of borrowing from the opinion is 9.84. As this hypothetical indicates, under certain conditions lower court opinions have an influence on the content of Supreme Court majority opinions, demonstrating the ability of the lower courts to shape the development of federal law.

\section{CONCLUSION}

The Supreme Court's majority opinions play an enormous role in the American legal and political systems. Within the legal system, these opinion act as precedents, constraining the behavior of lower court judges and future Supreme Courts. Moreover, majority opinions act as guides for litigants, shaping the arguments they make in their written briefs and during oral arguments. Within the broader political system, Supreme Court opinions influence the behavior of bureaucracies and further place limits on the content of legislation in congress and state legislatures. Despite the significance of Supreme Court opinions, few have systematically examined the factors that shape the content of the Court's majority opinions. The purpose of this research is to add to our understanding of the content of Supreme Court opinions by investigating the justices' reliance on lower court opinions in crafting the Court's majority opinions.

Our results indicate that the Supreme Court systematically incorporates language from lower court opinions into its own majority opinions. We find that the Court is especially likely to borrow from lower court opinions that were written by prestigious judges. Moreover, the Court relies more on published lower court opinions and those opinions that are congruent with the ideological direction of the Court's decision. Our results also provide evidence that the Court integrates more 
language from lower court majority opinions than separate opinions and is more reliant on U.S. Courts of Appeals opinions than U.S. District Court opinions. Taken as a whole, this research provides substantial insight into the factors that contribute to the content of the Supreme Court's majority opinions.

Beyond this paper's primary contribution to the greater understanding of the content of Supreme Court majority opinions, this research is significant in a number of other ways. First, it is indicative of the importance of understanding the judiciary as a web of interactions between different levels of the legal system. The Supreme Court formally sits at the apex of the judicial pyramid, with the lower courts typically viewed as subordinate, inferior entities charged with faithfully enacting the Supreme Court's policies. Indeed, many conceptualize Supreme Court as a principal directing (or attempting to direct) its agents, the lower courts (e.g., Benesh 2002; George and Yoon 2003; Songer, Segal, and Cameron 1994). Thus, previous literature analyzing the interaction between the Supreme Court and lower courts overwhelmingly focuses on lower court interpretation of, and compliance with, Supreme Court precedent (e.g., Canon and Johnson 1999; Klein 2002; Sanders 1995). In this paper, we demonstrate that the lower courts are not merely the Supreme Court's inferiors, but that the lower courts have the ability to shape the doctrinal force of federal law. Though the justices have substantial, if not total, control over the content of their opinions, it is clear that the Court does not start with a blank slate. Rather, the language of the Court's majority opinions is derived from many different sources, and one such source is the opinions of the lower courts that initially disposed of the case.

Second, this research corroborates the utility of using computerized text analysis to understand legal and political texts. While legal scholars have long investigated the content of the Supreme Court's opinions in order to understand the doctrinal development of federal law, they 
have overwhelmingly done so on an issue-by-issue or case-by-case basis, not fully taking advantage of more systematized research tools. As this paper reveals, much can be learned about legal and political texts by utilizing computer based text analysis programs, such as the plagiarism detection software used here, as well as other automated methods (e.g., Laver, Benoit, and Garry 2003). For example, future research might use plagiarism detection software to evaluate the extent to which legislation authored by interest groups makes its way into finished legislation. Similarly, one could profitably exploit this software to evaluate how presidential speeches shape print media coverage of the president.

While this research makes clear the importance of understanding the content of judicial opinions, while providing evidence that lower courts are capable of shaping the doctrinal content of Supreme Court opinions, it is but one piece of the puzzle. Accordingly, we encourage future research to investigate additional factors that shape Supreme Court opinions. For example, one might explore the extent to which other informational sources, such as amicus curiae briefs and oral arguments, influence the language of Supreme Court opinions. In addition, disentangling the positive and negative treatment of the lower court opinions is no doubt a most worthy endeavor. Further, research into the determinants of lower court opinion content, particularly with regard to the U.S. Courts of Appeals, will provide added insight into the doctrinal development of federal law. To be sure, the importance of understanding the content of judicial opinions cannot be overstated and we are certain that the addition of systematic research into this area will provide most welcome insight into the legal and political system. 


\section{REFERENCES}

Benesh, Sara C. 2002. The U.S. Court of Appeals and the Law of Confessions: Perspectives on the Hierarchy of Justice. New York: LFB Scholarly Publishing.

Bennett, Robert W. 2001. "Counter-Conversationalism and the Sense of Difficulty." Northwestern University Law Review 95(3): 845-906.

Bloomfield, Louis A. 2009. WCopyfind. http://plagiarism.phys.virginia.edu/Wsoftware.html (March $5,2009)$.

Brown v. Legal Foundation of Washington, 155 L. Ed. 2d 376 (2003).

Canon, Bradley C., and Charles A. Johnson, Jr. 1999. Judicial Policies: Implementation and Impact. $2^{\text {nd }}$ ed. Washington: CQ Press.

Collins, Paul M., Jr. 2004. "Friends of the Court: Examining the Influence of Amicus Curiae Participation in U.S. Supreme Court Litigation." Law and Society Review 38(4): 807-832.

Corley, Pamela C. 2008. 'The Supreme Court and Opinion Content: The Influence of Parties' Briefs.” Political Research Quarterly 61(3): 468-478.

Early, Stephen T., Jr. 1977. Constitutional Courts of the United States: The Formal and Informal Relationships between the District Courts, the Courts of Appeals, and the Supreme Court of the U.S. Totowa: Littlefield, Adams, and Co.

Epstein, Lee, and Jeffrey A. Segal. 2000. "Measuring Issue Salience.” American Journal of Political Science 44(1): 66-83.

Galanter, Marc. 1974. 'Why the 'Haves' Come Out Ahead: Speculations on the Limits of Legal Change." Law and Society Review 9(1): 95-160.

George, Tracey E., and Albert H. Yoon. 2003. “The Federal Court System: A Principal-Agent Perspective.” St. Louis University Law Journal 47(3): 819-834.

Greenburg, Jan Crawford. 2007 “Thomas and Oral Argument.” October 9.

http://blogs.abcnews.com/legalities/2007/10/thomas-and-oral.html (March 5, 2009).

Grimmer, Justin. 2009. “A Bayesian Hierarchical Topic Model for Political Texts: Measuring Expressed Agendas in Senate Press Releases.” Harvard University. Typescript.

Harmon, Robert R., and Kenneth A. Coney. 1982. "The Persuasive Effects of Source Credibility in Buy and Lease Situations.” Journal of Marketing Research 19(2): 255-260. 
Hass, R. Glen. 1981. "Effects of Source Characteristics on Cognitive Responses and Persuasion.” In Cognitive Responses in Persuasion, ed. Richard E. Petty, Thomas M. Ostrom, and Timothy C. Brock. Hillsdale: Lawrence Erlbaum Associates.

Hettinger, Virginia A., Stefanie A. Lindquist, and Wendy L. Martinek. 2006. Judging on a Collegial Court: Influences on Federal Appellate Decision Making. Charlottesville: University of Virginia Press.

Hovland, Carl I., and Walter Weiss. 1951. "The Influence of Source Credibility on Communication Effectiveness.” Public Opinion Quarterly 15(4): 635-650.

Johnson, Timothy R. 2004. Oral Arguments and Decision Making on the United States Supreme Court. Albany: State University of New York Press.

Johnson, Timothy R., Paul J. Wahlbeck, and James F. Spriggs, II. 2006. "The Influence of Oral Arguments on the U.S. Supreme Court.” American Political Science Review 100(1): 99-113.

Klein, David E. 2002. Making Law in the United States Courts of Appeals. Cambridge: Cambridge University Press.

Klein, David E., and Darby Morrisroe. 1999. "The Prestige and Influence of Individual Judges on the U.S. Courts of Appeals.” Journal of Legal Studies 28(2): 371-391.

Kunda, Ziva. 1990. “The Case for Motivated Reasoning.” Psychological Bulletin 108(3): 480-498.

Laver, Michael, Kenneth Benoit, and John Garry. 2003. "Extracting Policy Positions from Political Texts Using Words as Data.” American Political Science Review 97(2): 311-331.

Maltzman, Forrest, James F. Spriggs, II, and Paul J. Wahlbeck. 2000. Crafting Law on the Supreme Court: The Collegial Game. Cambridge: Cambridge University Press.

Merritt, Deborah Jones, and James J. Brudney. 2001. "Stalking Secret Law: What Predicts Publication in the United States Courts of Appeals." Vanderbilt Law Review 54(1): 71-121.

Morriss, Andrew P., Michael Heise, and Gregory C. Sisk. 2005. "Signaling and Precedent in Federal District Court Opinions." Supreme Court Economic Review 13: 63-97.

Perlof, Richard M. 2003. The Dynamics of Persuasion: Communication and Attitudes in the 21st Century. $2^{\text {nd }}$ ed. Mahwah: Lawrence Erlbaum Associates.

Perry, H.W., Jr. 1991. Deciding to Decide: Agenda Setting in the United States Supreme Court. Cambridge: Harvard University Press.

Pritchett, C. Herman. 1948. The Roosevelt Court: A Study in Judicial Politics and Values, 1937-1947. New York: Macmillan. 
Rosen, Mark D. 2005. "Modeling Constitutional Doctrine.” St. Louis University Law Journal 49(3): 691-707.

Rowland, C.K., and Robert A. Carp. 1996. Politics and Judgment in Federal District Courts. Lawrence: University of Kansas Press.

Sanders, Francine. 1995. "Brown v. Board of Education: An Empirical Reexamination of Its Effects on Federal District Courts." Law and Society Review 29(4): 731-756.

Samuels, Suzanne Uttaro. 2004. First among Friends: Interest Groups, the U.S. Supreme Court, and the Right to Privacy. Westport: Praeger Publishers.

Scalia, Antonin, and Bryan A. Garner. 2008. Making Your Case: The Art of Persuading Judges. St. Paul: Thompson/West.

Scott, Kevin M. 2006. "Understanding Judicial Hierarchy: Reversals and the Behavior of Intermediate Appellate Judges." Law and Society Review 40(1): 163-191.

Segal, Jeffrey A. 1986. "Supreme Court Justices as Human Decision Makers: An Individual-Level Analysis of the Search and Seizure Cases.” Journal of Politics 47(4): 938-955.

Segal, Jeffrey A., and Harold J. Spaeth. 2002. The Supreme Court and the Attitudinal Model Revisited. Cambridge: Cambridge University Press.

Shapiro, Martin. 1968. The Supreme Court and Administrative Agencies. New York: Free Press.

Songer, Donald R. 1990. "Criteria for Publication of Opinions in the U.S. Courts of Appeals: Formal Rules versus Empirical Reality.” Judicature 73(6): 307-313.

Songer, Donald R., Jeffrey A. Segal, and Charles M. Cameron. 1994. “The Hierarchy of Justice: Testing a Principal-Agent Model of Supreme Court-Circuit Court Interaction." American Journal of Political Science 38(3): 673-696.

Spaeth, Harold J. 2007. The Original United States Supreme Court Database, 1953-2006 Terms. East Lansing, MI: Department of Political Science, Michigan State University.

Spriggs, James F., II, and Paul J. Wahlbeck. 1997. "Amicus Curiae and the Role of Information at the Supreme Court.” Political Research Quarterly 50(3): 365-386.

Stern, Robert L., Eugene Gressman, Stephen M. Shapiro, and Kenneth S. Geller. 2002. Supreme Court Practice: For Practice in the Supreme Court of the United States. $8^{\text {th }}$ ed. Washington: Bureau of National Affairs.

Swenson, Karen. 2004. "Federal District Court Judges and the Decision to Publish." Justice System Journal 25(2): 121-142. 
Wahlbeck, Paul J. 1997. "The Life of the Law: Judicial Politics and Legal Change." Journal of Politics 59(3): 778-802.

Ward, Artemus, and David L. Weiden. 2006. Sorcerers' Apprentices: 100 Years of Law Clerks at the United States Supreme Court. New York: New York University Press.

Wasby, Stephen L. 2004. "Unpublished Court of Appeals Decisions: A Hard Look at the Process." Southern California Interdisciplinary Law Journal 14(1): 67-124. 
Table 1. Summary Statistics

\begin{tabular}{lllll}
\hline Variable & Mean & Std. Dev. & Min. & Max. \\
\hline & & & & \\
Dependent Variable & 4.316 & 4.382 & 0 & 23 \\
Judicial Prestige & 2.672 & 0.488 & 1 & 3 \\
Published Opinion & 0.841 & 0.367 & 0 & 1 \\
Ideological Congruence & 0.458 & 0.499 & 0 & 1 \\
Court of Appeals Majority Opinion & 0.461 & 0.499 & 0 & 1 \\
District Court Opinion & 0.287 & 0.453 & 0 & 1 \\
Opinion Length & 6.919 & 13.503 & 0.036 & 187.907 \\
Political Salience & 0.119 & 0.324 & 0 & 1 \\
Breyer & 0.087 & 0.282 & 0 & 1 \\
Ginsburg & 0.043 & 0.204 & 0 & 1 \\
Kennedy & 0.130 & 0.337 & 0 & 1 \\
O’Connor & 0.139 & 0.347 & 0 & 1 \\
Scalia & 0.148 & 0.356 & 0 & 1 \\
Souter & 0.177 & 0.382 & 0 & 1 \\
Stevens & 0.122 & 0.327 & 0 & 1 \\
Thomas & 0.090 & 0.286 & 0 & 1 \\
& & & & \\
\hline
\end{tabular}


Table 2. The Influence of Lower Federal Court Opinions on U.S. Supreme Court Majority Opinions, 2002-2004 Terms

\begin{tabular}{|c|c|}
\hline Variable & Coefficient \\
\hline Judicial Prestige $[+]$ & $\begin{array}{l}0.741 * * \\
(0.412)\end{array}$ \\
\hline Published Opinion $[+]$ & $\begin{array}{l}1.645^{* * *} \\
(0.556)\end{array}$ \\
\hline Ideological Congruence $[+]$ & $\begin{array}{c}0.642 * \\
(0.484)\end{array}$ \\
\hline Court of Appeals Majority Opinion $[+]$ & $\begin{array}{l}3.713^{* * *} \\
(0.513)\end{array}$ \\
\hline District Court Opinion $[+]$ & $\begin{array}{l}1.501 * * \\
(0.597)\end{array}$ \\
\hline Opinion Length $[+]$ & $\begin{array}{l}0.086^{* * *} \\
(0.025)\end{array}$ \\
\hline Political Salience $[-]$ & $\begin{array}{l}-1.081^{*} \\
(0.826)\end{array}$ \\
\hline Constant & $\begin{array}{l}-0.140 \\
(2.266)\end{array}$ \\
\hline $\begin{array}{l}\text { R-squared } \\
\text { F-test } \\
\mathrm{N}\end{array}$ & $\begin{array}{l}0.292 \\
7.430 * * * \\
345\end{array}$ \\
\hline \multicolumn{2}{|c|}{$\begin{array}{l}\text { The unit of analysis is the lower court opinion-Supreme Court } \\
\text { opinion dyad. The dependent variable is the percentage of the } \\
\text { Supreme Court opinion taken from the lower court opinion. Entries } \\
\text { are OLS regression coefficients. Numbers in parentheses are robust } \\
\text { standard errors, clustered on docket number. The expected direction } \\
\text { of the coefficients of the independent variables appears in brackets. } \\
\text { The model includes eight justice-specific dummy variables (results } \\
\text { not shown). }{ }^{* *} \mathrm{p}<.01,{ }^{* *} \mathrm{p}<.05,{ }^{*} \mathrm{p}<.10 \text { (one-tailed tests). }\end{array}$} \\
\hline
\end{tabular}


Figure 1. Percentage of U.S. Supreme Court Majority Opinions from Lower Federal Court Opinions, by Justice (2002-2004 Terms)

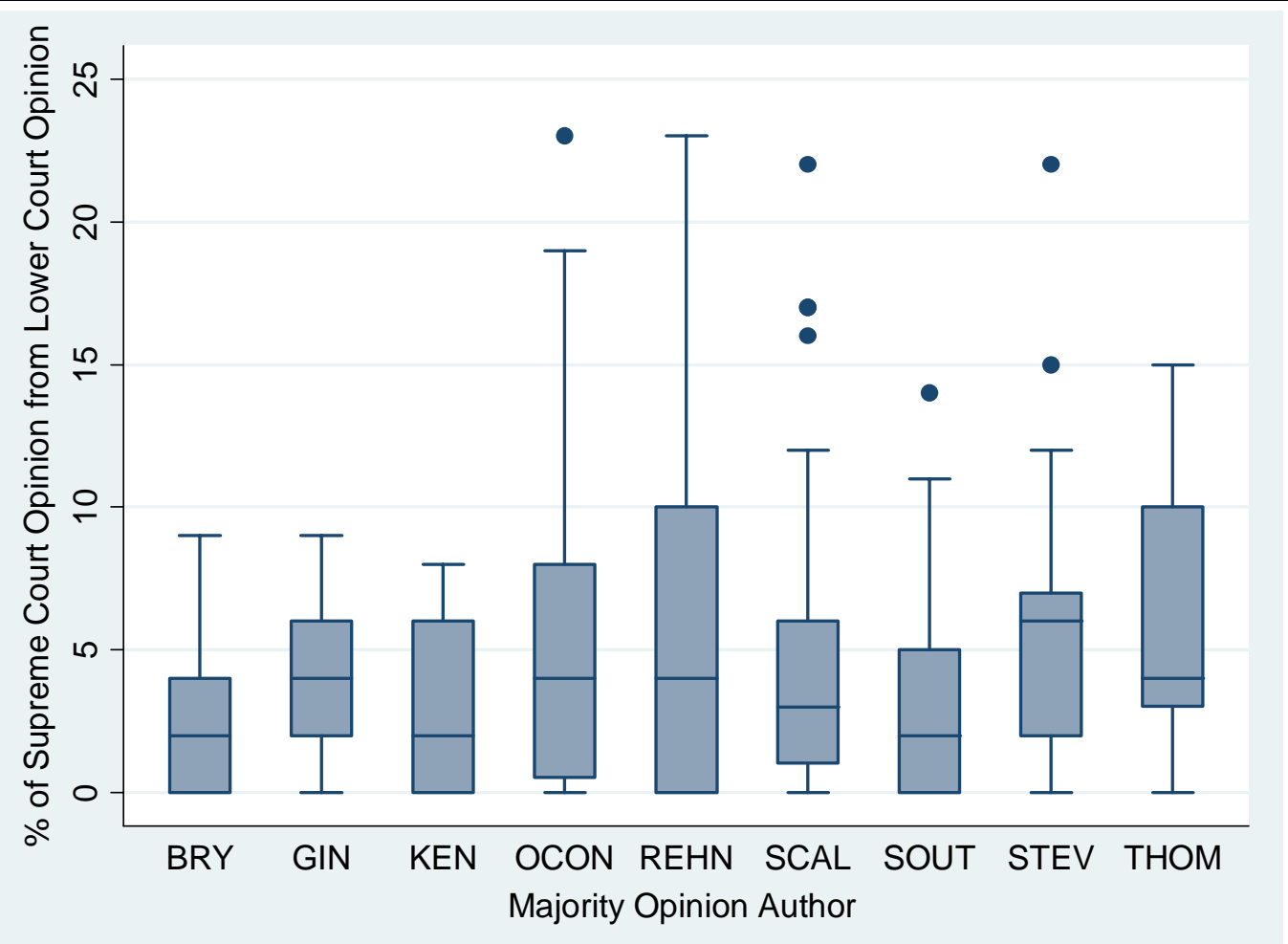

Note: BRY = Justice Breyer; GIN = Justice Ginsburg; KEN = Justice Kennedy; OCON = Justice O'Connor; REHN = Chief Justice Rehnquist; SCAL = Justice Scalia; SOUT $=$ Justice Souter; THOM = Justice Thomas 